(2) Open Access Full Text Article

REVIEW

\title{
Peramivir injection in the treatment of acute influenza: a review of the literature
}

\author{
Ashley Wester' \\ Avinash K Shetty ${ }^{2}$ \\ 'Department of Pharmacy, \\ ${ }^{2}$ Department of Pediatrics, Wake \\ Forest School of Medicine, Winston- \\ Salem, NC, USA
}

This article was published in the following Dove Press journal:

Infection and Drug Resistance

22 August 2016

Number of times this article has been viewed
Correspondence: Avinash K Shetty Department of Pediatrics, Wake Forest School of Medicine, Brenner Children's Hospital, Medical Center Boulevard, Winston-Salem, NC 27/57, USA

Tel +I 3367162740

Fax + I 3367169699

Email ashetty@wakehealth.edu
Abstract: Influenza virus infection is a major cause of morbidity and mortality in children and adults globally. Seasonal epidemics are common due to the rapid virus evolution, whereas the frequent emergence of antigenic variants can result in pandemics and sporadic/endemic avian influenza virus infections. Although annual vaccination is the mainstay for influenza prevention and control, the use of antiviral agents must be considered for treatment and prophylaxis against influenza. Currently available antiviral drugs include neuraminidase inhibitors (NAIs), adamantanes, and a novel polymerase inhibitor (favipiravir). Peramivir is a recently US Food and Drug Administration-approved NAI for the treatment of acute uncomplicated influenza in adults. The chemical structure of peramivir allows it to bind to the influenza neuraminidase with much higher affinity than oseltamivir. Peramivir is effective against a variety of influenza A and B subtypes and has a lower half-maximal inhibitory concentration compared to other NAIs in in vitro studies. Peramivir can be administered intravenously, a route that is favorable for hospitalized, critically ill patients with influenza. The long half-life of peramivir allows for once-daily dosing. The drug is eliminated primarily by the kidneys, warranting dose adjustments in patients with renal dysfunction. Studies have assessed the clinical efficacy of peramivir for treatment of pandemic influenza A (H1N1). Although anecdotal evidence supports the use of peramivir in pediatric patients, pregnant women, and hospitalized patients with severe influenza receiving continuous renal replacement therapy and extracorporeal membrane oxygenation, welldesigned, controlled clinical trials should be conducted in order to assess its clinical efficacy in these patient populations.

Keywords: peramavir, influenza, pharmacokinetics, safety, efficacy, review

\section{Introduction}

The influenza virus causes a highly infectious, acute respiratory illness that causes significant morbidity and mortality in children and adults both in the US as well as globally. ${ }^{1}$ Seasonal influenza affects between $5 \%$ and $20 \%$ of the population in the US annually, resulting in 25-50 million cases each year. ${ }^{1}$ This significant number of influenza cases leads to approximately 225,000 hospitalizations and is responsible for 36,000 deaths each year in the US alone. ${ }^{2}$ Globally, the WHO (World Health Organization) estimates that up to $20 \%$ of the population is infected with influenza each year, causing up to one billion infections, three-to-five-million cases of severe disease, and up to 300,000-500,000 deaths. ${ }^{3}$ Although endemics and pandemics of influenza have been surfacing for centuries, the pandemic influenza A (H1N1) that arose in the spring of 2009 was particularly devastating. The $2009 \mathrm{H} 1 \mathrm{~N} 1$ virus infected individuals in almost 
all countries globally and was responsible for 60.8 million cases, 273,304 hospitalizations, and 12,469 deaths, many of which were documented in pregnant women, indigenous populations, and in patients who were morbidly obese or had serious comorbidities. ${ }^{4,5}$

Despite the fact that the H1N1 pandemic revealed the need for better pandemic planning, it also illustrated the need for more effective antiviral agents for the treatment of severe influenza. ${ }^{6,7}$ In 2009, available therapies for acute influenza treatment included the adamantanes or M2 channel inhibitors and neuraminidase inhibitors (NAIs). M2 channel inhibitors include amantadine and rimantidine and have activity only against influenza A; however, the circulating H1N1 viruses were resistant to adamantanes and not recommended for treatment of influenza in the US. ${ }^{6,8}$ NAIs included oseltamivir (Tamifluß; Genentech USA, Inc., South San Francisco, CA, USA) and zanamivir (Relenza ${ }^{\circledR}$; GlaxoSmithKline, Brentford, UK), which have activity against both influenza A and B virus. ${ }^{6,8}$ Due to the fact that oseltamivir is administered orally and zanamivir is administered via the inhalation route, an unmet need for an intravenous (IV) antiviral agent existed for patients with severe influenza who were mechanically ventilated or critically ill. ${ }^{8}$ Peramivir (Rapivab ${ }^{\text {TM}}$; BioCryst Pharmaceuticals, Inc., Durham, NC, USA), an investigational NAI that was in advanced clinical development during the pandemic of 2009, is an IV NAI that was a promising therapy for patients with contraindications or poor response to available antivirals. ${ }^{8,9}$ Peramivir binds tightly to the neuraminidase (NA) enzyme compared to other NAIs and inhibits the growth of influenza A and B virus in vitro. ${ }^{10}$

Due to the favorable route of administration and promising Phase II trials, the US Food and Drug Administration (FDA) issued an Emergency Use Authorization (EUA) for this drug on October 23, 2009. ${ }^{8,9}$ Hospitalized patients were eligible for peramivir treatment if they were unresponsive to or were unable to tolerate available antivirals, or if oral and inhaled drug delivery routes were deemed unreliable. ${ }^{9}$ Under the EUA, health care providers were required to monitor and report medication errors, adverse events (AEs), and deaths to the FDA Adverse Event Reporting System. ${ }^{9}$

From the date of the EUA issuance through June 23, 2010, 1,371 requests for peramivir were submitted to the Centers for Disease Control and Prevention (CDC), and 2,129 5-day adult treatment courses were delivered to 563 hospitals. ${ }^{8}$ Following a survey of health care providers, 1,274 patients had received at least one dose of peramivir. ${ }^{8}$ The median age of peramivir recipients was 43 years (range, 0-92 years); 49\% of patients were male. ${ }^{8}$ The Adverse Event Reporting System reports were completed for 344 patients and included 28 children and 3 pregnant women ${ }^{9} ; 41 \%$ of patients for whom reports were received were critically ill and on mechanical ventilation, and $19 \%$ were on renal replacement therapies. ${ }^{9}$

Serious AEs reported included death (15\%), H1N1 influenza ( $8 \%$ ), respiratory failure ( $8 \%$ ), acute renal failure $(7 \%)$, and acute respiratory distress syndrome (7\%); additionally, six medication errors were reported. ${ }^{9}$ Most patients who died during or following peramivir therapy were obese, immunosuppressed, $>65$ years, or had also received oseltamivir. ${ }^{9}$ The only treatment-emergent $\mathrm{AE}$ that was reported and found to be attributable to peramivir was development of rash. ${ }^{9}$ Other reports of AEs with peramivir use were confounded by severity of influenza disease, comorbidities, and concomitant medications. ${ }^{9}$ Following the evaluation of reported AEs during the EUA, it was concluded that many of the patients who suffered AEs were critically ill and therefore at risk of developing complications that may or may not be attributable to the drug use itself. ${ }^{9}$ Peramivir has been the subject of several excellent reviews. ${ }^{10-12}$

Peramivir has been approved for influenza treatment in both Japan and South Korea since 2010. In December 2014, peramivir was approved by the FDA for the treatment of acute, uncomplicated influenza in adults who have been symptomatic for $\leq 2$ days. ${ }^{13}$ This review will outline the new literature that has been published in recent years so as to provide a better understanding of peramivir's mechanism of action, pharmacology, clinical efficacy, safety, and tolerability, as well as its current place in influenza therapy.

\section{Microbiology overview and pharmacology of peramivir Structure and mechanism of action}

Peramivir, like other NAIs, binds to the active site of the influenza virus NA enzyme in order to prevent spread of infectious virions. Two glycoproteins are important to facilitate the influenza virus to infect host cells, the aforementioned NA, as well as hemaglutinin. The hemaglutinin protein allows viral entry, while NA promotes release of the virus from infected host cells so as to continue to spread the infection. ${ }^{14}$ When peramivir binds to the active NA site on the virus, it is able to mimic the sialic acid residues present in the viral membrane to compete with neuraminic acid binding, which in turn prevents virion release. ${ }^{7,15-18}$

The peramivir molecule (Figure 1) contains a carboxylate group, a guanidino group, and lipophilic side chains off the cyclopentane backbone. ${ }^{19}$ Its empirical formula is $\mathrm{C}_{15} \mathrm{H}_{34} \mathrm{~N}_{4} \mathrm{O}_{4} \cdot 3 \mathrm{H}_{2} \mathrm{O}$, with a molecular weight of $328.45 \mathrm{~g} / \mathrm{mol}$. The chemical structure of peramivir allows it to bind to the 


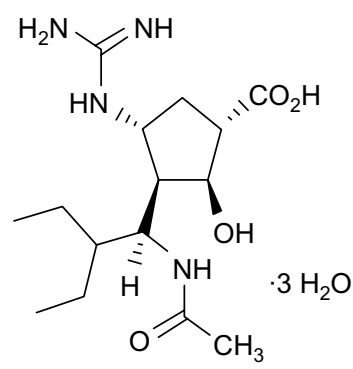

Figure I Chemical structure of peramivir.

influenza NA with much higher affinity than oseltamivir carboxylate, despite the similar structure in the cyclopentane backbone of the two drugs. ${ }^{20,21}$ The interaction between the NA arginine residue at position 292 and the carboxylic acid groups on zanimivir and oseltamivir allow binding of the drugs to the influenza NA. Additionally, the glutamic acid residue at position 119 in the NA enzyme interacts with the basic structures of zanimivir (guanidinium) and oseltamivir (amine) and allows for the difference in drug resistance profiles. ${ }^{19,20,22,23}$ Peramivir's negatively charged carboxylate group allows for hydrogen bonding, while the acetamido group binds to the NA's hydrophobic pocket. Strong hydrogen bonds and electrostatic interactions are also formed between the peramivir's positively charged guanidinium group and the carboxylates of the NA. ${ }^{19,20,22,23}$ Due to these structural characteristics, the peramivir molecule has the ability to bind to the N9 site of the NA for a prolonged period of time (about 24 hours) with a slow dissociation rate. ${ }^{20,23}$

\section{Pharmacokinetics}

The pharmacokinetic (PK) parameters of peramivir are outlined in Table $1 .{ }^{24}$ Oral administration of peramivir was assessed in a Phase III clinical trial, but was not found to

Table I PK parameters after a single dose of peramivir

\begin{tabular}{ll}
\hline PK parameter & $\begin{array}{l}\text { Value in adult with } \\
\text { normal renal function }\end{array}$ \\
\hline Route & Intravenous \\
Dose & $600 \mathrm{mg}$ \\
Kinetics & Linear \\
Protein binding & $<30 \%$ \\
$C_{\max }$ & $46,800 \mathrm{ng} / \mathrm{mL}$ \\
AUC ${ }_{0-\infty}$ & $102,700 \mathrm{ng} \cdot \mathrm{h} / \mathrm{mL}$ \\
Plasma $t_{1 / 2}$ elimination in healthy adults & Approximately 20 hours \\
$V_{d}$ & $12.56 \mathrm{~L}$ \\
Metabolism & Minimal \\
Excretion & Renal $(90 \%)$ \\
Dose adjustment for renal insufficiency & Yes \\
Dose adjustment for hepatic insufficiency & No \\
\hline
\end{tabular}

Abbreviations: PK, pharmacokinetic; max, maximum; AUC, area under the curve; $\mathrm{V}_{\mathrm{d}}$, volume of distribution; $C_{\text {max }}$, maximum serum concentration. achieve statistical significance in the treatment group. ${ }^{25} \mathrm{Sub}$ sequently, it was found to have very low bioavailability $(<3 \%)$, which led to the development and assessment of parenteral formulations. ${ }^{23}$ Several Phase I clinical trials ${ }^{24}$ have been conducted to assess the PK parameters of both intamuscular (IM) and IV administration of peramivir in healthy adults, which have shown a linear relationship between the dose and maximum serum concentration $\left(C_{\max }\right)$ as well as area under the curve (AUC).$^{24}$ Additionally, single-dose injections of IV and IM peramivir have been found to be bioequivalent. A Phase I, two-period crossover study was conducted in healthy volunteers, which found that peramivir administered via the IV and IM route to the same subjects at doses of 75 to $600 \mathrm{mg}$ led to bioequivalence of the two routes when AUC was compared. Researchers also determined that the absolute bioavailability of IM peramivir ranged from $92 \%$ to $100 \%$ and that overall drug administration was safe and well tolerated. ${ }^{26}$

Matsuo et $\mathrm{al}^{27}$ conducted a recent study of population PK in both healthy volunteers and influenza patients to assess factors that influence the PK parameters of peramivir. The study utilized 3,199 plasma concentration samples from 332 subjects that were analyzed from six trials conducted in Japan and the US. Subjects included healthy patients, patients with influenza, and patients with renal impairment. Researchers found that the plasma concentrations of peramivir were well described by a three-compartment model. Additionally, they determined that the most important factor influencing peramivir PK was creatinine clearance $\left(\mathrm{CL}_{\mathrm{CR}}\right)$, owing to the fact that peramivir is primarily renally excreted. Age was also found to be related to peramivir clearance, while body weight was a factor in the volume of distribution of the drug, primarily when it came to the central compartment of the model. There were no differences between the Japanese or US subjects, and sex was also found to have no effects on peramivir PK. The study also utilized Monte Carlo simulations to determine that patients with a $\mathrm{CL}_{\mathrm{CR}}>50 \mathrm{~mL} / \mathrm{min}$ required no dose adjustment, while patients with a $\mathrm{CL}_{\mathrm{CR}}$ of $30-50 \mathrm{~mL} / \mathrm{min}$ should have a 1/3-fold dose adjustment, and those with $\mathrm{CL}_{\mathrm{CR}} 10-30$ $\mathrm{mL} / \mathrm{min}$ should have a 1/6-fold dose adjustment in order to achieve AUCs comparable to patients with normal renal function. ${ }^{27}$ Studies have also been conducted to assess PK parameters of peramivir following single doses of the drug in both healthy and infected patients.

Zhang et $\mathrm{al}^{28}$ explored the PK profile of peramivir in healthy Chinese subjects through an open-label, randomized, single-dose, crossover study. They utilized doses of 300 and $600 \mathrm{mg}$, both given intravenously, and collected blood and urine samples at 17 designated time points and seven 
designated time intervals for up to 36 hours postdose. They found that the drug displays linear PKs at the tested doses and noted increases in $C_{\max }$ and AUC in proportion to the dose given. ${ }^{28}$ Sato et $\mathrm{al}^{29}$ assessed 28 pediatric patients who were treated with $10 \mathrm{mg} / \mathrm{kg}$ of IV peramivir to determine the predictive peramivir concentration-time curve against the viruses with decreased susceptibility to NAIs. They found that peramivir concentration decreased to $<0.1 \%$ of the $C_{\max }$ at 24 hours postadministration. They concluded that peramivir readministration should be considered in the event of lack of clinical improvement in patients with normal susceptibility to influenza A and B and that better viral inhibition and lower frequency of adverse effects may be expected with divided administration. $^{29}$

To date, no clinical trials have been specifically conducted to assess the PK parameters of peramivir in patients undergoing continuous renal replacement therapy (CRRT) or extracorporeal membrane oxygenation (ECMO). Case reports of peramivir use in patients on CRRT have shown that peramivir has high clearance by various forms of CRRT, including continuous venovenous hemofiltration. A recent report by Bentley et $\mathrm{al}^{30}$ assessed the PK parameters of a 29-year-old female receiving peramivir during continuous venovenous hemodiafiltration, which were consistent with those of previous reports. The dialysate flow rate was 16.7 $\mathrm{mL} / \mathrm{min}$, producing a total ultrafiltrate of $14.2 \mathrm{~mL} / \mathrm{min}$. They obtained both pre- and postfilter peramivir samples from blood and effluent at 4.5 and 8.5 hours following the third dose of $480 \mathrm{mg}$ of peramivir, as well as plasma concentrations at several time points for measurement of AUC. Researchers found the $C_{\text {max }}$ at 30 minutes to be $19,477 \mathrm{ng} / \mathrm{mL}, C_{\min }$ to be $2,750 \mathrm{ng} / \mathrm{mL}$, and $\mathrm{AUC}_{0-24 \mathrm{~h}}$ to be $196,166 \mathrm{ng} \cdot \mathrm{h} / \mathrm{mL}$. The plasma half-life was estimated to be 8.2 hours, and researchers noted a log-linear decrease over the 24-hour period.
Thus, peramivir was found to have significant clearance with continuous venovenous hemodiafiltration with a calculated saturation coefficient of 0.98 , which was very close to the estimated saturation coefficient of $1 .{ }^{30}$ Additionally, Tang et $\mathrm{a}^{31}$ describe the successful use of peramivir in a patient with acute respiratory distress syndrome caused by the influenza A virus H7N9 who underwent continuous venovenous hemodiafiltration in addition to venovenous ECMO. Though they do not report PK parameters in their patient, they do describe that they were able to remove her from venovenous ECMO support after 13 days. Dedicated studies of peramivir use in advanced forms of life support as well as in CRRT will provide valuable information for clinicians who desire to use peramivir in their clinical practice with critically ill patients.

\section{Spectrum of antivirus activity}

Peramivir has activity against both influenza $A$ and influenza $B$ viruses as demonstrated by both in vivo and in vitro studies. ${ }^{20,23}$ The potent antiviral effects of the drug confer activity against pandemic and highly pathogenic strains of influenza subtypes H5N1 and H9N2. Additionally, peramivir has the ability to inhibit the replication of nine different types of avian influenza viruses. ${ }^{32}$ In an experimental mouse model of H7N9 avian influenza virus infection, repeated doses of peramivir at $30 \mathrm{mg} / \mathrm{kg}$ body weight demonstrated antiviral activity resulting in the resolution of clinical signs, improved survival, and prevention of recurrence of neurological symptoms. ${ }^{33}$

Recent studies have been conducted on isolates of previous influenza seasons to determine the susceptibility of the viruses to NAIs. Table 2 outlines the susceptibility profiles of these viruses as evaluated by two studies conducted by Dapat et $\mathrm{al}^{34}$ and Leang et al. ${ }^{35}$ Dapat et $\mathrm{al}^{34}$ assessed the susceptibility of influenza virus isolates during the 2009-2010 and 2010-2011 seasons in Japan and showed that type A influenza

Table 2 In vitro neuraminidase inhibitor activity against influenza $A$ and $B$ viruses

\begin{tabular}{|c|c|c|c|c|c|c|c|c|c|c|c|}
\hline \multirow[t]{2}{*}{ Study } & \multirow[t]{2}{*}{ Virus } & \multirow[t]{2}{*}{ Duration } & \multirow[t]{2}{*}{$\mathbf{N}$} & \multicolumn{2}{|c|}{ 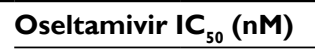 } & \multicolumn{2}{|c|}{ Zanamivir IC ${ }_{50}(\mathrm{nM})$} & \multicolumn{2}{|c|}{ Peramivir $I C_{50}(\mathrm{nM})$} & \multicolumn{2}{|c|}{ Laninamivir $I C_{50}(n M)$} \\
\hline & & & & Range & Mean \pm SD & Range & Mean \pm SD & Range & Mean \pm SD & Range & Mean \pm SD \\
\hline \multirow{6}{*}{$\begin{array}{l}\text { Dapat } \\
\text { et } \mathrm{al}^{34}\end{array}$} & $\mathrm{~A}(\mathrm{HINI})$ & 2009-2010 & 57 & $1.48-10.9 \mid$ & $1.88 \pm 0.25$ & $0.49-1.92$ & $0.69 \pm 0.09$ & $0.04-0.22$ & $0.07 \pm 0.0 \mathrm{I}$ & $0.16-0.49$ & $0.24 \pm 0.05$ \\
\hline & pdm09 & & & & & & & & & & \\
\hline & $\mathrm{A}(\mathrm{HINI})$ & $2010-2011$ & 60 & $0.72-443.95$ & $\mid .37 \pm 0.3 \mathrm{I}$ & $0.30-1.79$ & $0.63 \pm 0.14$ & $0.07-37.09$ & $0.12 \pm 0.03$ & $0.20-0.66$ & $0.27 \pm 0.05$ \\
\hline & pdm09 & & & & & & & & & & \\
\hline & $\mathrm{A}(\mathrm{H} 3 \mathrm{~N} 2)$ & $2010-2011$ & 59 & $0.46-2.12$ & $0.73 \pm 0.20$ & $0.4 I-2.66$ & $0.63 \pm 0.17$ & $0.10-0.33$ & $0.17 \pm 0.04$ & $0.30-1.09$ & $0.65 \pm 0.15$ \\
\hline & B & $2010-2011$ & 18 & $16.97-59.12$ & $27.09 \pm 11$ & $29.33-92.3$ & $53.74 \pm 17.25$ & $1.22-4.77$ & $2.3 I \pm 0.88$ & $4.69-15.23$ & $8.44 \pm 3.33$ \\
\hline \multirow{4}{*}{$\begin{array}{l}\text { Leang } \\
\text { et } \mathrm{al}^{35}\end{array}$} & $\mathrm{~A}(\mathrm{HINI})$ & $2009-2012$ & 580 & - & - & - & - & - & $0.17 \pm 0.10$ & - & $0.27 \pm 0.05$ \\
\hline & pdm09 & & & & & & & & & & \\
\hline & $\mathrm{A}(\mathrm{H} 3 \mathrm{~N} 2)$ & $2009-2012$ & 1,949 & - & - & - & - & - & $0.18 \pm 0.08$ & - & $0.62 \pm 0.05$ \\
\hline & B & $2009-2012$ & $\mid, 231$ & - & - & - & - & - & $0.74 \pm 0.33$ & - & $3.26 \pm 0.26$ \\
\hline
\end{tabular}

Note: Data from previous studies. ${ }^{34,35}$

Abbreviations: $\mathrm{IC}_{50}$, half-maximal inhibitory concentration; SD, standard deviation. 
isolates were more susceptible to the NAIs in comparison to type B isolates. They noted that the half-maximal inhibitory concentration $\left(\mathrm{IC}_{50}\right)$ values for peramivir and laninamivir were significantly lower than those for oseltamivir and zanamivir, signifying a higher in vitro susceptibility of the viruses to peramivir and laninamivir. Researchers also examined eight $\mathrm{A}(\mathrm{H} 1 \mathrm{~N} 1)$ pdm09 viruses and one type $\mathrm{B}$ virus from patients following treatment with NAIs. The authors determined that there was an increase in prevalence of the $\mathrm{H} 274 \mathrm{Y}$ mutation in the influenza A(H1N1)pdm09 from the 2009-2010 season to the 2010-2011 season and that patients with this mutation were resistant to treatment with oseltamivir and peramivir but retained susceptibility to zanamivir and laninamivir. Despite the discovery of other mutations in the isolated viruses and the widespread use of NAIs, researchers concluded that the prevalence of NAI-resistant influenza viruses in Japan remains low. ${ }^{34}$

Leang et $\mathrm{al}^{35}$ collected influenza viruses from 19 countries in Asia, Africa, and Oceania between 2009 and 2012 to evaluate their susceptibility to peramivir and laninamivir. In addition to the $\mathrm{IC}_{50}$ values recorded in Table 2 for viruses with normal inhibition, researchers determined that 19 of the total $599 \mathrm{~A}(\mathrm{H} 1 \mathrm{~N} 1)$ pdm09 viruses had highly reduced peramivir inihibition due to $\mathrm{H} 275 \mathrm{Y}$ NA substitution upon genetic evaluation. Despite this increase in $\mathrm{H} 275 \mathrm{Y}$ variants, the authors concluded that there were no marked changes in the frequency of peramivir-resistant variants despite the widespread use of NAIs. ${ }^{35}$ Both these studies highlight the necessity for continuous susceptibility monitoring to determine if the viruses are developing resistance to these new NAIs.

\section{Development of antiviral resistance}

Emerging resistance of influenza viruses to antiviral agents, including the NAIs, is becoming an important public health concern for clinicians. Treatment options are affected by circulating resistant strains of the influenza virus and put patients at risk for treatment failure. Due to structural differences involving the chemical moieties involved in NA binding among the available NAIs, influenza resistance has been shown to be agent-specific. ${ }^{36}$ Despite this, research by the WHO shows that influenza viruses in the Western Pacific, the Americas, and Europe have developed highly reduced inhibition to at least one of the four NAIs. ${ }^{37}$

One of the most well-studied mutations that confers resistance among influenza viruses is the $\mathrm{H} 275 \mathrm{Y}$ substitution in the NA protein. Mutations of this substitution have been found to confer a 400-fold decrease in susceptibility to oseltamivir and 140-fold decrease in susceptibility to peramivir in comparison to wild-type viruses. ${ }^{38}$ Two case reports by Memoli et $\mathrm{al}^{39}$ demonstrate the ability of wild-type influenza viruses to develop mutations during therapy, specifically in immunocompromised hosts. One patient with a history of myelodysplastic syndrome and stem cell transplantation was treated with oseltamivir for influenza A infection for an extended period of time. Upon analysis of viral isolates throughout her treatment course, it was found that the initial wild-type virus had acquired an H275Y mutation by day 9 of oseltamivir therapy. Similarly, in a second patient, an H275Y mutation that resulted in significant reduction in viral susceptibility was recovered after 14 days of treatment with oseltamivir. ${ }^{39}$ While development of NA substitutions has been specifically noted in patients who have received treatment with NAIs, Takashita et $\mathrm{al}^{40}$ have also identified patients with $\mathrm{H} 275 \mathrm{Y}$ mutations that have never received prior treatment with NAIs. Six viruses in Japan were isolated in November and December of 2013, and though no epidemiological link was identified between the viruses, they were found to be closely genetically related. This finding suggests spread of a single resistant virus. ${ }^{40}$

A CDC analysis of 87 specimens from 58 patients utilized pyrosequencing to determine that $\mathrm{H} 275 \mathrm{Y}$ mutations were present in $38 \%$ of isolates from the 2009 influenza pandemic. In isolates that exhibited the $\mathrm{H} 275 \mathrm{Y}$ variant at $\geq 50 \%$, resistance to oseltamivir and peramivir was detected, though full susceptibility to zanamivir was retained. Additional substitutions were recovered from two patients, I223K or I22KR substitutions, and were found to have 38-52-fold enhancement in susceptibility to oseltamivir and 33-97-fold enhancement to peramivir. ${ }^{41}$

Takashita et $\mathrm{al}^{38}$ aimed to monitor the emergence of NAI-resistant viruses in four influenza seasons from 2008 to 2012. Using allelic discrimination, gene sequencing, and susceptibility profiles, researchers determined that the detection rate of resistant viruses had increased from $1 \%$ in the 2009 pandemic season to $2 \%$ in the postpandemic period. They also found that $1.3 \%$ of over $12,000 \mathrm{~A}(\mathrm{H} 1 \mathrm{~N} 1) \mathrm{pdm} 09$ isolates had acquired an $\mathrm{H} 275 \mathrm{Y}$ substitution and that, in general, patients who were between 0 and 9 years had the highest detection rate for resistant viruses. ${ }^{38} \mathrm{~A}$ report of community transmission of oseltamivir-resistant A(H1N1) pdm09 in Australia advocates for rapid analysis of potentially transmissible virus strains. Twenty-nine viruses analyzed contained $\mathrm{H} 275 \mathrm{Y}$ substitutions, and upon hemagglutinin and NA sequence analysis, it was determined that the strains were closely genetically related and likely accounted for the spread of a single variant. ${ }^{42}$ 
Other mutations are less common but have been associated with reduced susceptibility to NAIs. A report of an $\mathrm{A}(\mathrm{H} 3 \mathrm{~N} 2)$ virus, $\mathrm{A} / \mathrm{Ohio} / 88 / 2012$, was found to contain two rare substitutions, $\mathrm{S} 245 \mathrm{~N}$ and $\mathrm{S} 247 \mathrm{P}$. Researchers found that there was a 31 -fold reduction in oseltamivir susceptibility and 66-fold reduction in peramivir susceptibility, which was mostly due to the SN247P mutation. ${ }^{43}$ Additionally, highly reduced inhibition was demonstrated in an $\mathrm{A}(\mathrm{H} 3 \mathrm{~N} 2)$ virus with an NA E119V mutation, a B/Yamagata-lineage with an $\mathrm{H} 273$ Y mutation, as well as a B/Victoria-lineage strain with an NA E117G mutation. ${ }^{37}$ Overall, the concern for development of viral resistance to the currently available NAIs is justified and suggests that continued research be done to determine ways to decrease the spread of resistant influenza strains. ${ }^{44}$

\section{Clinical efficacy and comparative trials of peramivir}

A compilation of randomized controlled trials of IV and IM peramivir in adult patients is provided in Table $3 .{ }^{45-52}$ Additional clinical trials, including open-label randomized trials as well as retrospective observational studies, are provided in Table 4. ${ }^{9,53-55,60}$

\section{Clinical trials of ambulatory patients with influenza}

Two multicenter, phase II, randomized, double-blind, placebocontrolled trials were conducted by BioCryst Pharmaceuticals, Inc. in adult patients with positive rapid antigen tests (RATs) for influenza. ${ }^{45,46}$ The first study assessed 344 subjects who were randomized to receive a single dose of peramivir $150 \mathrm{mg}$ IM, peramivir $300 \mathrm{mg}$ IM, or placebo within 48 hours of symptom onset. The study found no statistically significant differences between treatment groups for the primary end point, time to alleviation of symptoms. ${ }^{45}$ The second study evaluated peramivir $600 \mathrm{mg}$ IM as a single dose versus placebo, also in adult patients with symptom duration of $<48$ hours. From the 334 patients who completed the efficacy analysis, researchers concluded that there were no statistically significant differences between treatment groups for time to alleviation of symptoms. ${ }^{46}$ In general, these studies found that peramivir was safe and well tolerated. ${ }^{45,46}$

In 2010, Kohno et $\mathrm{al}^{47}$ conducted an additional multicenter, phase II, randomized, double-blind, placebo-controlled trial in adult patients aged 20-64 years with influenza diagnosed by RATs. Subjects received peramivir $300 \mathrm{mg}$ or $600 \mathrm{mg}$ as a single IV dose or placebo within 48 hours of symptom onset. The primary end point was time to symptom alleviation, and 296 patients were included in the efficacy analysis. Statistically significant differences were found for both doses of peramivir compared to placebo, with a hazard ratio of $0.681(P=0.0092)$ for the peramivir $300 \mathrm{mg}$ group and $0.666(P=0.0092)$ for the peramivir $600 \mathrm{mg}$ group. This corresponded to a median time to symptom alleviation of 59.1 and 59.9 hours in the 300 and $600 \mathrm{mg}$ peramivir groups, respectively, compared to 82 hours in the placebo group. ${ }^{47}$ To assess the time to symptom alleviation in ambulatory patients with high-risk influenza symptoms, Kohno et $\mathrm{al}^{48}$ then conducted a phase III, randomized, double-blind, uncontrolled study in which patients received peramivir $300 \mathrm{mg}$ IV or peramivir $600 \mathrm{mg}$ IV for 1-5 days. Thirty-seven patients were included, and the study determined that the median time to symptom alleviation was 68.6 hours in all patients. Researchers found that the $600 \mathrm{mg}$ peramivir group had a significantly shorter duration of illness compared to the 300 mg group. Additionally, they determined that multiple doses of peramivir conferred more rapid symptom alleviation than single doses of peramivir. ${ }^{48}$

Kohno et $\mathrm{al}^{49}$ conducted a multicenter, phase III, randomized, double-blind, double-dummy trial in adult patients with acute uncomplicated influenza A or B diagnosed by RATs. Patients were randomized to receive peramivir IV at doses of 300 or $600 \mathrm{mg}$ as a single dose or oral osteltamivir at a dose of $75 \mathrm{mg}$ twice daily for 5 days. The study found that the 1,091 patients included in the efficacy analyses had similar time to alleviation of symptoms in all three treatment groups: 78 hours for the $300 \mathrm{mg}$ peramivir group, 81 hours for the $600 \mathrm{mg}$ peramivir group, and 81.8 hours for the oseltamivir group. Based on the hazard ratios of $0.946(95 \% \mathrm{CI}, 0.793-1.129)$ for the $300 \mathrm{mg}$ peramivir group and 0.970 (95\% CI, 0.814-1.157) for the $600 \mathrm{mg}$ peramivir group, researchers concluded that both peramivir regimens were noninferior to the oseltamivir group. ${ }^{49}$

\section{Clinical trials of hospitalized patients with influenza}

Ison et $\mathrm{al}^{50}$ conducted a multicenter, phase II trial in hospitalized patients with acute or potentially life-threatening influenza in which patients were randomized to receive peramivir $200 \mathrm{mg}$, peramivir $400 \mathrm{mg}$, or placebo intravenously for 5 days in combination with oseltamivir or oral placebo. Researchers found no significant differences in the time to clinical stability or time to resumption of normal activities between groups and similarly found no differences between changes in viral titers at 48 hours. Thus, they concluded that peramivir was noninferior to oseltamivir in this patient population and had no significant differences in dose response between peramivir groups. ${ }^{50}$ 
Table 3 Clinical efficacy of peramivir: randomized controlled trials of IV or IM peramivir in adults

\begin{tabular}{|c|c|c|c|c|c|}
\hline Study & $\begin{array}{l}\text { Location/sponsorl } \\
\text { trial ID }\end{array}$ & Design & $\begin{array}{l}\text { Population/ } \\
\text { sample size }\end{array}$ & Regimen & Results \\
\hline \multicolumn{6}{|c|}{ Ambulatory patients with acute uncomplicated influenza (normal hosts) } \\
\hline $\begin{array}{l}\text { Biocryst } \\
\text { NCT004I9263 }\end{array}$ & US/Canada/Biocryst & $\begin{array}{l}\text { Phase II, } \\
\text { randomized, } \\
\text { double-blind, } \\
\text { placebo- } \\
\text { controlled, } \\
\text { multicenter }\end{array}$ & $\begin{array}{l}\text { Adults with } \\
\text { positive rapid } \\
\text { antigen test } \\
\text { for influenza }\end{array}$ & $\begin{array}{l}\text { Peramivir I } 50 \\
\mathrm{mg}, 300 \mathrm{mg} \text {, or } \\
\text { placebo as IM single } \\
\text { dose }<48 \text { hours of } \\
\text { symptom onset }\end{array}$ & $\begin{array}{l}\text { Completed } \\
\text { ( } \mathrm{n}=344) \\
\text { No statistically significant differences between } \\
\text { treatment groups for time to alleviation of } \\
\text { symptoms (primary endpoint) } \\
\text { Improvement over placebo was } 22.9 \text { hours with } \\
\text { I50 mg dose }(P=0.284) \text { and } 21.1 \text { hours with the } \\
300 \mathrm{mg} \text { dose }(P=0.152)\end{array}$ \\
\hline Atiee et $\mathrm{a}^{46}$ & $\begin{array}{l}\text { US, Australia, New } \\
\text { Zealand, South Africa/ } \\
\text { Biocryst }\end{array}$ & $\begin{array}{l}\text { Phase II, } \\
\text { randomized, } \\
\text { double-blind, } \\
\text { placebo- } \\
\text { controlled, } \\
\text { multicenter }\end{array}$ & $\begin{array}{l}\text { Adults with } \\
\text { positive } \\
\text { influenza A or } \\
\text { B (by RAT) } \\
\text { with symptom } \\
\text { duration } \leq 48 \\
\text { hours }\end{array}$ & $\begin{array}{l}\text { Peramivir } 600 \mathrm{mg} \\
\text { versus placebo as } \\
\text { IM single dose }\end{array}$ & $\begin{array}{l}\text { Completed } \\
\text { ( } \mathrm{n}=402, \mathrm{n}=334 \text { efficacy analyses) } \\
\text { No statistically significant differences between } \\
\text { treatment groups for time to alleviation of } \\
\text { symptoms (primary endpoint) } \\
\text { Median time to alleviation } 91 . \mathrm{I} \text { hours for } 600 \\
\text { mg IM injection of peramivir and I06.I hours for } \\
\text { placebo } \\
\text { Peramivir generally safe and well tolerated }\end{array}$ \\
\hline Kohno et $\mathrm{al}^{47}$ & $\begin{array}{l}\text { Japan/ } \\
\text { Shionogi/0722T062I }\end{array}$ & $\begin{array}{l}\text { Phase II, } \\
\text { randomized, } \\
\text { double-blind, } \\
\text { placebo- } \\
\text { controlled } \\
\text { multicenter }\end{array}$ & $\begin{array}{l}\text { Adults aged } \\
20-64 \text { years } \\
\text { with influenza } \\
\text { symptoms } \\
\text { and positive } \\
\text { influenza A or } \\
\text { B (by RAT) }\end{array}$ & $\begin{array}{l}\text { Peramivir } 300 \\
\text { or } 600 \mathrm{mg} \text { IV } \\
\text { single dose versus } \\
\text { placebo }<48 \\
\text { hours of onset of } \\
\text { symptoms }\end{array}$ & $\begin{array}{l}\text { Completed ( } \mathrm{n}=300, \mathrm{n}=296 \text { efficacy analyses) } \\
\text { Statistically significant difference for both doses } \\
\text { of peramivir compared with placebo for time to } \\
\text { symptom alleviation (HR, } 0.68 \mathrm{I}[P=0.0092] \text { in } \\
300 \mathrm{mg} \text { group and } 0.666[P=0.0092] \text { in the } 600 \\
\mathrm{mg} \text { group compared to placebo; adjusted } P \text {-value } \\
0.0092 \text { for both comparisons) } \\
\text { The median time to alleviation of symptoms was } \\
59.1 \text { hours after } 300 \mathrm{mg} \text { peramivir, } 59.9 \text { hours } \\
\text { after } 600 \mathrm{mg} \text { peramivir compared to } 82 \text { hours } \\
\text { for placebo }\end{array}$ \\
\hline Kohno et $\mathrm{al}^{49}$ & $\begin{array}{l}\text { Japan/ } \\
\text { Shionogi/08I5T063I }\end{array}$ & $\begin{array}{l}\text { Phase III, } \\
\text { randomized, } \\
\text { double-blind, } \\
\text { double-dummy, } \\
\text { controlled, } \\
\text { multicenter }\end{array}$ & $\begin{array}{l}\text { Adults aged } \\
\geq 20 \text { years } \\
\text { with influenza } \\
\text { symptoms } \\
\text { and positive } \\
\text { influenza A or } \\
\text { B (by RAT) }\end{array}$ & $\begin{array}{l}\text { Peramivir } 300 \mathrm{mg} \\
\text { or } 600 \mathrm{mg} \text { IV single } \\
\text { dose versus oral } \\
\text { oseltamivir } 75 \mathrm{mg} \\
\text { BID } \times 5 \text { days }\end{array}$ & $\begin{array}{l}\text { Completed } \\
\text { ( } \mathrm{n}=1,093, \mathrm{n}=1,09 \mathrm{I} \text { efficacy analyses) } \\
\text { Similar time to symptom alleviation (primary } \\
\text { endpoint) for all three treatment groups ( } 78 \\
\text { hours for } 300 \mathrm{mg} \text { peramivir, } 8 \mathrm{I} \text { hours for } 600 \mathrm{mg} \\
\text { peramivir, and } 81.8 \text { hours for oseltamivir) } \\
\text { The hazard ratios of the } 300 \text { - and } 600-\mathrm{mg} \text { groups } \\
\text { compared to the oseltamivir group were } 0.946 \\
(97.5 \% \mathrm{Cl}, 0.793-1.129) \text { and } 0.970 \\
(97.5 \% \mathrm{Cl}, 0.814-1.157) \text {, respectively } \\
\text { Both peramivir groups were noninferior to the } \\
\text { oseltamivir group }(97.5 \% \mathrm{Cl},<1.170 \text { ) }\end{array}$ \\
\hline \multicolumn{6}{|c|}{ High-risk ambulatory patients with acute uncomplicated influenza } \\
\hline Kohno et $\mathrm{al}^{48}$ & $\begin{array}{l}\text { Japan/ } \\
\text { Shionogi/08I6T0632 }\end{array}$ & $\begin{array}{l}\text { Phase III, } \\
\text { randomized, } \\
\text { double-blind, } \\
\text { uncontrolled, } \\
\text { multicenter }\end{array}$ & $\begin{array}{l}\text { High-risk } \\
\text { patients with } \\
\text { influenza } \\
\text { symptoms } \\
\text { and positive } \\
\text { influenza A or B } \\
\text { (by RAT) }\end{array}$ & $\begin{array}{l}\text { Peramivir } 300 \text { or } 600 \\
\mathrm{mg} I V \times I-5 \text { days } \\
\text { B }\end{array}$ & $\begin{array}{l}\text { Completed } \\
\text { ( } \mathrm{n}=37 \text { efficacy analyses) } \\
\text { The median time to symptom alleviation was } 68.6 \\
\text { hours ( } 90 \% \mathrm{Cl}, 4 \mathrm{I} .5-\mathrm{II} 3.4 \text { hours) in all patients } \\
\text { The duration of influenza illness was significantly } \\
\text { shorter (hazard ratio, } 0.497 ; 90 \% \mathrm{Cl}, 0.25-0.984 \text { ) } \\
\text { in the } 600 \mathrm{mg} \text { group than in the } 300 \mathrm{mg} \text { group } \\
\text { Patients who received multiple doses of } \\
\text { peramivir showed more rapid symptom } \\
\text { alleviation compared to those who received } \\
\text { single doses }\end{array}$ \\
\hline
\end{tabular}


Table 3 (Continued)

\begin{tabular}{|c|c|c|c|c|c|}
\hline Study & $\begin{array}{l}\text { Location/sponsor/ } \\
\text { trial ID }\end{array}$ & Design & $\begin{array}{l}\text { Population/ } \\
\text { sample size }\end{array}$ & Regimen & Results \\
\hline \multicolumn{6}{|c|}{ Hospitalized patients with influenza } \\
\hline Ison et $\mathrm{al}^{50}$ & $\begin{array}{l}\text { US, Australia, Canada, } \\
\text { Hong Kong, New } \\
\text { Zealand, Singapore, } \\
\text { South Africa/Biocryst/ } \\
\text { NCT00453999 }\end{array}$ & $\begin{array}{l}\text { Phase II, } \\
\text { randomized, } \\
\text { double-blind, } \\
\text { double dummy, } \\
\text { placebo- } \\
\text { controlled, } \\
\text { multicenter }\end{array}$ & $\begin{array}{l}\text { Hospitalized } \\
\text { patients with } \\
\text { acute or } \\
\text { potentially } \\
\text { life- } \\
\text { threatening } \\
\text { influenza }\end{array}$ & $\begin{array}{l}\text { Peramivir } 200,400 \\
\text { mg, or placebo IV } \\
\text { QD ×5 days plus } \\
\text { either oseltamivir } \\
\text { oral suspension or } \\
\text { placebo } 75 \mathrm{mg} \text { BID } \\
\times 5 \text { days }\end{array}$ & $\begin{array}{l}\text { Completed } \\
\text { ( } n=137, n=122 \text { efficacy analyses) } \\
\text { No significant differences in the time to } \\
\text { clinical stability (primary end point) or time to } \\
\text { resumption of normal activities and change in } \\
\text { viral titers at } 48 \text { hours (secondary end points) } \\
\text { between any of the treatment groups } \\
\text { Peramivir was non-inferior to oseltamivir in } \\
\text { hospitalized patients with acute influenza and } \\
\text { demonstrated similar tolerability } \\
\text { No significant difference in dose response among } \\
\text { the peramivir groups }\end{array}$ \\
\hline Hernandez et $\mathrm{al}^{51}$ & $\begin{array}{l}\text { USA, Australia, } \\
\text { Canada, New Zealand, } \\
\text { Mexico, Puerto Rico/ } \\
\text { Biocryst \& US DHHS/ } \\
\text { NCT00957996 }\end{array}$ & $\begin{array}{l}\text { Phase III, } \\
\text { randomized, } \\
\text { open-label }\end{array}$ & $\begin{array}{l}\text { Hospitalized } \\
\text { adults and } \\
\text { adolescents } \\
\text { (I4-92 } \\
\text { years) with } \\
\text { confirmed } \\
\text { or suspected } \\
2009 \\
\text { pandemic } \\
\text { influenza } \\
\text { (HINI) }\end{array}$ & $\begin{array}{l}\text { Peramivir } 300 \mathrm{mg} \\
\text { IV BID or } 600 \mathrm{mg} \\
\text { IV QD }\end{array}$ & $\begin{array}{l}\text { Completed } \\
\text { ( } \mathrm{n}=234) \\
\text { Primary outcome: similar reduction in influenza } \\
\text { virus titer in nucleoprotein samples over the } \\
\text { first } 48 \text { hours for both groups ( }-1.66 \text { [ } 95 \% \mathrm{Cl} \text {, } \\
-2.32 \text { to }-0.6 \mathrm{I}] \text { for } 300 \mathrm{mg} \text { peramivir twice daily } \\
\text { and }-1.47 \text { [ } 95 \% \mathrm{Cl},-1.89 \text { to }-0.75] \text { for } 600 \mathrm{mg} \\
\text { peramivir once daily) } \\
\text { The analysis of the combined intention-to-treat } \\
\text { population showed median time to resolution of } \\
\text { fever was } 25.3 \text { hours; time to clinical resolution, } \\
92 \text { hours; time to alleviation of symptoms, I } 45 \\
\text { hours; and time to resumption of usual activities, } \\
26.8 \text { days }\end{array}$ \\
\hline de Jong et $\mathrm{al}^{52}$ & $\begin{array}{l}\text { North and South } \\
\text { America, Europe, South } \\
\text { Africa/Biocryst \& US } \\
\text { DHHS/NCT00958776 }\end{array}$ & $\begin{array}{l}\text { Phase III, } \\
\text { randomized, } \\
\text { double-blind, } \\
\text { controlled, } \\
\text { multicenter }\end{array}$ & $\begin{array}{l}\text { Hospitalized } \\
\text { adolescents } \\
\text { and adults } \\
\text { ( } \geq 12 \text { years) } \\
\text { who have } \\
\text { suspected or } \\
\text { confirmed } \\
\text { influenza } \\
\text { as shown } \\
\text { by positive } \\
\text { influenza A/B } \\
\text { RAT }\end{array}$ & $\begin{array}{l}\text { Peramivir + SOC } \\
\text { versus SOC + } \\
\text { placebo without } \\
\mathrm{NAI} \text {; peramivir } \\
\text { + SOC versus } \\
\text { placebo + SOC } \\
\text { with NAI; adults: } \\
\text { peramivir } 600 \text { mg } \\
\text { IV QD; adolescents: } \\
\text { peramivir I0 mg/kg } \\
\text { (max. } 600 \mathrm{mg} \text { ) QD }\end{array}$ & $\begin{array}{l}\text { Terminated during preplanned interim analysis } \\
\text { for futility ( } n=338) \\
\text { Primary outcome for non-NAl group: time to } \\
\text { clinical resolution at day } 5 \text { was similar between } \\
\text { groups ( } 42.5 \text { hours for peramivir versus } 49.5 \\
\text { hours for placebo; } P=0.97) \\
\text { Secondary outcome: greater reductions in } \\
\text { viral shedding were observed in patients who } \\
\text { received peramivir, though not statistically } \\
\text { significant } \\
\text { Incidence and severity of adverse events were } \\
\text { similar between groups }\end{array}$ \\
\hline
\end{tabular}

Abbreviations: BID, two times a day; $\mathrm{Cl}$, confidence interval; HR, hazard ratio; IM, intramuscular; IV, intravenous; NAls, neuraminidase inhibitors; QD, every day; RAT, rapid antigen test; SOC, standard of care.

A phase III, randomized, open-label study was conducted by the National Institutes of Health in hospitalized patients aged 14-92 years with confirmed or suspected H1N1 influenza. ${ }^{51}$ Patients received peramivir $300 \mathrm{mg}$ IV twice daily or peramivir $600 \mathrm{mg}$ IV once daily and were found to have similar reduction in influenza virus titers over the first 24 hours. An analysis of the intention-to-treat population revealed a median time to fever resolution of 25.3 hours, with time to clinical resolution of 92 hours, time to symptom alleviation of 145 hours, and time to resumption of usual activities of 26.8 days. ${ }^{51}$ An additional randomized, double-blind, controlled, phase III study was conducted by the National Institutes of Health to assess peramivir use in hospitalized adults and adolescents with influenza confirmed through RAT. Time to clinical resolution at day 5 was the primary outcome and was determined to be 42.5 hours for peramivir versus 49.5 hours for placebo $(P=0.97)$. Due to these results, this study was terminated following a preplanned interim analysis. ${ }^{52}$

Additional studies have demonstrated the clinical effects of peramivir in adult patients. ${ }^{53,54} \mathrm{An}$ open-label, randomized trial of hospitalized patients of $\geq 6$ years of age was conducted by Ison et $a l^{54}$ to determine viral titer decline between two peramivir regimens. A total of 234 patients were randomized to receive either peramivir $300 \mathrm{mg}$ IV twice daily (or $5 \mathrm{mg} / \mathrm{kg}$ twice daily for patients $<18$ years) or peramivir $600 \mathrm{mg}$ IV 
Table 4 Other clinical studies of peramivir in influenza infection in adult and pediatric patients

\begin{tabular}{|c|c|c|c|c|}
\hline Study & Design & Population/sample size & Regimen & Results/conclusion \\
\hline \multicolumn{5}{|c|}{ Adults } \\
\hline Yoshino et $\mathrm{al}^{53}$ & Retrospective cohort & $\begin{array}{l}\text { Adults }>18 \text { years of age } \\
\text { hospitalized from October } \\
2012 \text { to March } 2013 ; n=32\end{array}$ & $\begin{array}{l}\text { Peramivir } 300 \mathrm{mg} \text { IV } \\
\text { once (or adjusted for } \\
\text { renal dysfunction or } \\
\text { severity) versus oral } \\
\text { oseltamivir } 75 \mathrm{mg} \text { BID } \\
\text { for } 5 \text { days }\end{array}$ & $\begin{array}{l}\mathrm{n}=23 \text { in peramivir group, } \mathrm{n}=9 \text { in } \\
\text { oseltamivir group } \\
\text { No difference between peramivir and } \\
\text { oseltamivir groups for time to defervescence } \\
(30.9 \pm 18.7 \text { hours versus } 34.7 \pm 18.6 \text { hours) or } \\
\text { survival rate ( } 95.7 \% \text { versus } 100 \%) \text { respectively } \\
\text { Concluded that the clinical efficacy of } \\
\text { peramivir is noninferior to that of oseltamivir }\end{array}$ \\
\hline Ison et $\mathrm{al}^{54}$ & $\begin{array}{l}\text { Open-label, randomized } \\
\text { trial }\end{array}$ & $\begin{array}{l}\text { Hospitalized patients } \geq 6 \text { years } \\
\text { of age; } n=234\end{array}$ & $\begin{array}{l}\text { Peramivir } 300 \mathrm{mg} \text { IV } \\
\text { twice daily versus } \\
\text { peramivir } 600 \mathrm{mg} \text { IV } \\
\text { once daily for adults } \geq 18 \\
\text { years or } 5 \mathrm{mg} / \mathrm{kg} \text { twice } \\
\text { daily versus } 10 \mathrm{mg} / \mathrm{kg} \\
\text { once daily for children } \\
\text { and adolescents }\end{array}$ & $\begin{array}{l}\text { Viral titers declined similarly without } \\
\text { difference between regimens; no significant } \\
\text { differences in virologic endpoints between } \\
\text { arms } \\
\text { Peramivir was found to be safe and well } \\
\text { tolerated }\end{array}$ \\
\hline \multicolumn{5}{|l|}{ Children } \\
\hline Sugaya et $\mathrm{a}^{55}$ & $\begin{array}{l}\text { Multicenter, open-label, } \\
\text { uncontrolled trial }\end{array}$ & $\begin{array}{l}\text { Hospitalized children age } \\
\geq 28 \text { days to }<16 \text { years with } \\
\text { influenza infection during the } \\
2009 \text { pandemic } A \text { (HINI) } \\
\text { epidemic; } n=106\end{array}$ & $\begin{array}{l}\text { Peramivir IV } 10 \mathrm{mg} / \mathrm{kg} \\
\text { (max. } 600 \mathrm{mg} \text { ) } \\
\text { once daily }\end{array}$ & $\begin{array}{l}\text { Median time to alleviation of symptoms was } \\
29.1 \text { hours ( } 95 \% \mathrm{Cl}, 22.1-32.4 \text { hours) } \\
\text { Concluded that peramivir is clinically and } \\
\text { virologically effective and safe in children with } \\
\text { pHINI virus infection }\end{array}$ \\
\hline $\begin{array}{l}\text { Shobugawa } \\
\text { et } \mathrm{al}^{56}\end{array}$ & Observational trial & $\begin{array}{l}\text { Outpatient pediatric patients; } \\
\mathrm{n}=263 ; \text { oseltamivir }=104, \\
\text { peramivir }=4 \text {; patients treated } \\
\text { with peramivir were age } \\
8.8 \pm 3.9 \text { years }\end{array}$ & $\begin{array}{l}\text { Peramivir IV } 10 \mathrm{mg} / \\
\mathrm{kg}(\mathrm{max} .600 \mathrm{mg} \text { ) as a } \\
\text { single dose; oseltamivir } \\
\mathrm{I} 50 \mathrm{mg} \text { per day divided } \\
\text { BID for children }>37.5 \\
\mathrm{~kg} \text { or } 4 \mathrm{mg} / \mathrm{kg} \text { per day } \\
\text { divided BID for children } \\
<37.5 \mathrm{~kg}\end{array}$ & $\begin{array}{l}\text { Peramivir group had the fastest time to } \\
\text { fever alleviation of all groups (median } 17.0 \\
\text { hours; } 95 \% \mathrm{Cl}, 7.2-26.8 \text { hours); result was } \\
\text { statistically significant compared to oseltamivir } \\
\text { group }(P=0.044 \text { ) }\end{array}$ \\
\hline Hikita et a ${ }^{48}$ & $\begin{array}{l}\text { Retrospective chart } \\
\text { review }\end{array}$ & $\begin{array}{l}\text { Outpatient pediatric patients } \\
\text { aged } 0-18 \text { years; total } n=223 \\
\text { - influenza A patients aged } \\
5-18 \text { years: peramivir }=15 \text {, } \\
\text { laninamivir }=1 \text {, zanamivir } \\
=18 \\
\text { - influenza B patients aged } \\
5-18 \text { years: peramivir }=13 \text {, } \\
\text { laninamivir }=13 \text {, zanamivir } \\
=20\end{array}$ & $\begin{array}{l}\text { Peramivir IV } 10 \text { mg/kg } \\
\text { (max. } 300 \mathrm{mg} \text { ) } \\
\text { once daily }\end{array}$ & $\begin{array}{l}\text { In influenza } A \text { patients aged } 5-18 \text { years, } \\
\text { median fever duration with peramivir } \\
\text { was shorter at I day compared to that of } \\
\text { zanamivir at } 2 \text { days }(P=0.0242) \\
\text { In influenza } B \text { patients aged } 5-18 \text { years, median } \\
\text { fever duration was } 3 \text { days with laninamivir } \\
\text { versus I day with peramivir ( } P=0.0097) \\
\text { Concluded that peramivir is very useful in } \\
\text { pediatric influenza patients }\end{array}$ \\
\hline \multicolumn{5}{|c|}{ Critically ill patients (adults and children) } \\
\hline Sorbello et $\mathrm{al}^{9}$ & $\begin{array}{l}\text { Retrospective chart } \\
\text { review of adverse events } \\
\text { reported during the EUA }\end{array}$ & $\begin{array}{l}\text { Hospitalized patients aged } \\
<\text { I to } 90 \text { years; } n=344\end{array}$ & $\begin{array}{l}\text { Not described, median } \\
\text { duration of peramivir } \\
\text { was } 5 \text { days }\end{array}$ & $\begin{array}{l}\text { The only treatment-emergent adverse event } \\
\text { found to be attributable to peramivir was rash }\end{array}$ \\
\hline Louie et $\mathrm{a}^{60}$ & $\begin{array}{l}\text { Retrospective } \\
\text { comparative analysis of } \\
\text { critically ill patients who } \\
\text { received peramivir versus } \\
\text { critically ill patients } \\
\text { treated with other } \\
\text { neuraminidase inhibitors }\end{array}$ & $\begin{array}{l}\text { Hospitalized patients with } \\
\mathrm{A}(\mathrm{HINI}) \text { pdm09 infection } \\
\text { aged } 5 \text { months to } 8 \mathrm{I} \text { years; } \\
\mathrm{n}=57 \text { patients who received } \\
\text { peramivir }\end{array}$ & Not described & $\begin{array}{l}\text { Twenty-nine }(5 \mid \%) \text { patients treated with } \\
\text { peramivir died } \\
\text { Fatal peramivir cases were more likely to have } \\
\text { acute renal failure }(P=0.02) \text {, shorter length of } \\
\text { hospital stay }(P=0.002) \text {, and shorter duration } \\
\text { or peramivir ( } 7 \text { versus } 9 \text { days; } P=0.02) \\
\text { compared to nonfatal cases } \\
\text { Peramivir patients were more likely to die } \\
\text { than non-peramivir patients }(P<0.0001) \text {, which } \\
\text { could be due to the preexisting severity of } \\
\text { disease prior to peramivir treatment }\end{array}$ \\
\hline
\end{tabular}

Abbreviations: $\mathrm{BID}$, twice daily; $\mathrm{Cl}$, confidence interval; EUA, emergency use authorization; IV, intravenous. 
once daily (or $10 \mathrm{mg} / \mathrm{kg}$ once daily for patients $<18$ years). The study found that viral titers declined similarly between the two regimens and that there were no significant differences in virologic end points between the arms. In general, peramivir was found to be both safe and well tolerated in both regimens. ${ }^{54}$

\section{Observational studies of pediatric patients with influenza}

While retrospective and uncontrolled trials have been emerging to assess the use of peramivir in pediatric patients in recent years, randomized controlled trials are yet to have been conducted in this patient population. A multicenter, open-label trial was conducted by Sugaya et $\mathrm{al}^{55}$ that evaluated patients $\geq 28$ days old but $<16$ years old who were hospitalized during the $2009 \mathrm{H} 1 \mathrm{~N} 1$ epidemic. Patients received peramivir $10 \mathrm{mg} / \mathrm{kg}$ IV at a maximum of $600 \mathrm{mg}$ once daily. The median time to alleviation of symptoms was 29.1 hours, and the drug was found to be both clinically and virologically effective as well as safe in pediatric patients. ${ }^{55}$ An observational trial of pediatric outpatients was conducted to assess time to fever alleviation with use of various NAIs. ${ }^{56}$ Out of a total of 263 patients, four received peramivir as a single dose of $10 \mathrm{mg}$ / $\mathrm{kg}$ (maximum of $600 \mathrm{mg}$ ). The peramivir group was found to have a median time to fever alleviation of 17 hours, which was the fastest of all the NAI groups and was found to be a statistically significant time difference when compared to the oseltamivir group $(P=0.044) .{ }^{56}$

Hikita et $\mathrm{al}^{57}$ also conducted a retrospective chart review of pediatric outpatients and found that in patients aged 5-18 years with influenza $A$, the duration of fever with peramivir was shorter in comparison to patients treated with zanamivir. In patients with influenza B within the same age group, fever duration was found to be significantly shorter in patients treated with peramivir versus those treated with laninamivir $(P=0.0097)$. Although a number of studies of peramivir use in children and adolescents has been reported, it is difficult to draw conclusions given small sample sizes or lack of information regarding number of patients treated with peramivir. ${ }^{58,59}$ Further studies should assess both the safety and efficacy of peramivir in children.

\section{Retrospective studies of critically ill adults and children}

In one retrospective comparative analysis, researchers evaluated hospitalized, critically ill patients aged 5 months to 81 years, of whom 57 received peramivir. They found that $51 \%$ of patients who received peramivir died, but that fatal peramivir cases were more likely to have developed acute renal failure, had a shorter length of hospital stay, and received a shorter course of peramivir as compared to patients who did not receive the drug. While patients who received peramivir were found to be more likely to die than those who did not receive it $(P<0.0001)$, researchers hypothesized that this was likely due to the preexisting severity of the patient cases prior to receiving peramivir treatment itself, but also that more studies should be conducted to assess the safety of peramivir in the critically ill patient population. ${ }^{60}$

\section{Antiviral combination therapy for severe influenza}

The role of antiviral combinations and antiviral-immunomodulator combination therapy for severe influenza has been reviewed recently. ${ }^{61}$ Preclinical studies demonstrate a potential for combination therapy including NAIs (such as oseltamivir or IV zanamivir or IV peramivir as a foundation drug) in conjunction with antiviral agents with different mechanisms of action. No key PK interactions have been observed in healthy volunteers receiving IV peramivir and oral oseltamivir. ${ }^{62}$ Well-designed controlled clinical trials must be conducted to investigate the efficacy of novel combination therapies for severe influenza infections, especially those caused by novel viruses such as $2009 \mathrm{H} 1 \mathrm{~N} 1$, avian influenza A H5N1, or the avian influenza A H7N9. ${ }^{61}$

\section{Safety and tolerability in clinical use of peramivir}

The most commonly reported AEs as well as the warnings and precautions as outlined in the package insert by BioCryst Pharmaceuticals are outlined in Table $5 .^{63}$

Two studies assessing adverse events of peramivir were conducted by BioCryst Pharmaceuticals in hospitalized patients with influenza. ${ }^{64}$ BCX1812-301 was a randomized, double-blind, placebo-controlled trial that assessed the incidence of adverse effects in patients receiving peramivir $600 \mathrm{mg}$ IV once daily for 5-10 days in addition to standard of care, which could include an additional NAI ${ }^{64} \mathrm{~A}$ total of 398 patients were included in the study, 88 of whom received peramivir alone and 176 of whom received peramivir in addition to another NAI. Researchers determined that the incidence of adverse effects did not increase with the use of peramivir in addition to oseltamivir and that the incidence of AEs in patients receiving peramivir was similar to that of patients receiving standard of care alone. In this trial, the majority of adverse effects involved the gastrointestinal tract, laboratory parameters, or were infectious or respiratory in nature. ${ }^{64}$ The second trial, BCX1812-303, prohibited the 
Table 5 Safety summary for peramivir

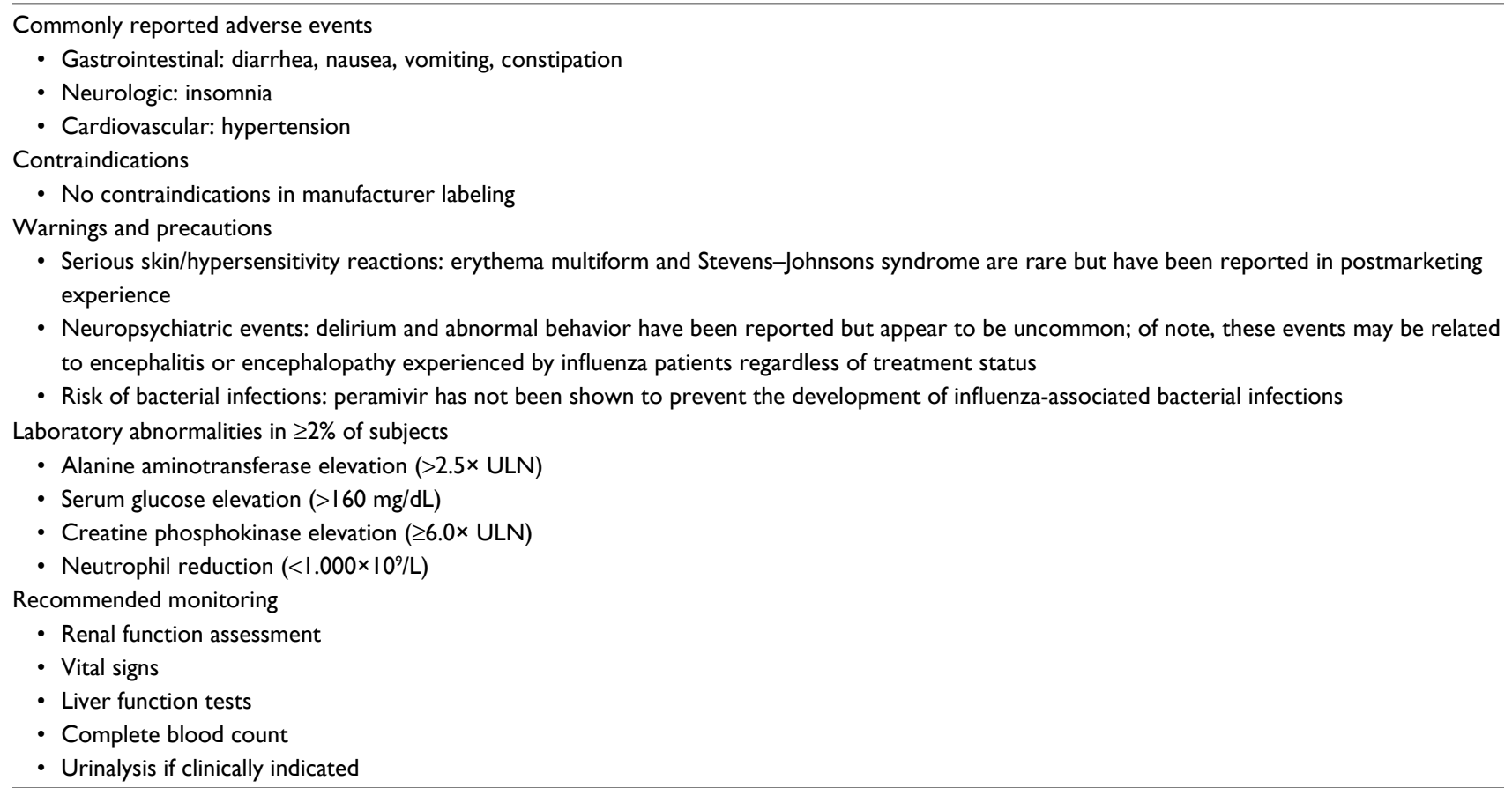

Note: Data from previous research. ${ }^{63}$

Abbreviation: ULN, upper limit of normal.

use of concomitant NAIs and assessed the differences in adverse effects between a peramivir regimen of $600 \mathrm{mg}$ IV daily versus peramivir $300 \mathrm{mg}$ IV twice daily. The trial concluded that the incidence of adverse effects was similar between groups and that gastrointestinal side effects were seen most commonly. ${ }^{64}$

Komeda et al ${ }^{65,66}$ conducted postmarketing drug use investigations of peramivir in both adult and pediatric populations. Safety was assessed in 1,174 adult patients from October 2010 to February 2012, and it was determined that the incidence rate of adverse drug reactions (ADRs) was $4.34 \%$ $(51 / 1,174)$. Diarrhea, vomiting, and nausea were the most frequently reported, with incidence rates of $1.87 \%, 0.85 \%$, and $0.68 \%$, respectively. No ADRs were reported as serious in this patient population, and $91 \%$ of ADRs arose within 3 days of peramivir administration, with $96.2 \%$ of them being resolved or improved within 7 days of onset. Safety was also assessed in 1,199 pediatric patients aged $<15$ years. Two hundred forty-five AEs were observed, corresponding to an incidence rate of $14.01 \%(168 / 1,199)$. ADRs accounted for 115 of these events, and commonly reported symptoms were diarrhea and abnormal behavior. Fourteen serious ADRs were observed among 12 patients and included five cases of abnormal behavior as well as five cases of decreased neutrophil count. The majority of events (87\%) occurred within 3 days of peramivir initiation, and $87.8 \%$ had resolved or improved within 7 days of onset. Overall, these two studies concluded that peramivir is safe in both adult and pediatric populations. ${ }^{65,66}$

While peramivir has been found to be generally safe and effective in most patient populations, case reports have been published which demonstrate that rare adverse effects have occurred. Hayashi et al ${ }^{67}$ reported a case of a 73-year-old woman with myasthenia gravis who experienced acute respiratory failure and an exacerbation of myasthenia gravis following IV peramivir treatment for influenza A. Investigators reported a decrease in oxygen saturation and altered consciousness within 20 minutes of peramivir administration in this patient. ${ }^{68}$ Additionally, Harada-Shirado et al ${ }^{68}$ reported a case of severe immune thrombocytopenia in a 44-year-old male patient being treated with peramivir for influenza A infection. Bone marrow findings and peripheral blood examination were consistent with immune thrombocytopenia, and further testing revealed a drug-induced lymphocyte-stimulating test with positivity to peramivir.

\section{Patient-focused perspectives}

In general, peramivir has been found to be well tolerated by patients in clinical trials. Peramivir can be administered intravenously, a route that is favorable for hospitalized, critically ill patients with influenza. Since peramivir is a 
parenteral agent that requires IV or IM administration, it is most appropriate to administer in a clinic or in inpatient setting. Many patients who will be treated with full a course of peramivir are likely to be critically ill; therefore, adherence to the once-daily medication regimen will be overseen by the inpatient health care team. Widespread seasonal immunization and optimal use of antiviral agents including peramivir are key tools in our armamentarium against the influenza virus.

Data regarding drug interactions with peramivir are lacking. The manufacturer labeling recommends to avoid use of live attenuated influenza vaccine within 2 weeks before or 48 hours after peramivir administration due to the NAI's ability to inhibit viral replication and therefore reduce vaccine efficacy. Since peramivir is not hepatically metabolized, the concern for cytochrome P450-mediated drug interactions is very low. In clinical trials, peramivir was not shown to have interactions with oral rimantidine, oseltamivir, oral contraceptives, or probenacid. ${ }^{63}$

\section{Conclusion}

Peramivir is a recently FDA-approved NAI for the treatment of influenza A and B. As a parenteral agent, it can be given via IV administration, a route that may be favorable for the critically ill population, although studies have shown that enteral administration of standard doses of oseltamivir has adequate absorption with therapeutic blood levels in critically ill adult patients. ${ }^{69,70}$ The long half-life of peramivir allows for once-daily dosing; however, due to elimination primarily by the kidneys, dose adjustments are required in patients with renal dysfunction. Peramivir has been shown to be efficacious against a variety of influenza A and B subtypes and has been found to have a lower $\mathrm{IC}_{50}$ compared to other NAIs in in vitro studies. Several studies have been conducted to assess its clinical efficacy for treatment of A(H1N1)pdm09, and trials continue to be conducted to assess its utility in postpandemic influenza. Studies of peramivir demonstrating an effect on hospitalizations or mortality are lacking. The efficacy of peramivir in hospitalized patients with severe influenza needs further investigation. Though case reports and retrospective studies support the use of peramivir in pediatric patients, pregnant women, and patients undergoing CRRT and ECMO, well-designed, controlled clinical trials should be conducted in order to assess its clinical efficacy in these patient populations.

\section{Disclosure}

The authors report no conflicts of interest in this work.

\section{References}

1. Ruuskanen O, Lahti E, Jennings LC, Murdoch DR. Viral pneumonias. Lancet. 2011;377(9773):1264-1275.

2. Fiore AE, Uyeki TM, Broder K, et al. Prevention and control of influenza with vaccines. MMWR Morb Mortal Wkly Rep. 2010;59(RR-8):1-62.

3. World Health Organization (WHO). Influenza (seasonal). Fact Sheet; March 2014. Geneva, Switzerland: World Health Organization; 2014. Available from: http://www.who.int/mediacentre/factsheets/fs211/en/. Accessed June 23, 2014.

4. Girard MP, Cherian T, Pervikov Y, Kieny MP. A review of vaccine research and development: human acute respiratory infections. Vaccine. 2005;23(50):5708-5724.

5. Shrestha SS, Swerdlow DL, Borse RH. Estimating the burden of 2009 pandemic influenza A (H1N1) in the United States (April 2009-2010). Clin Infect Dis. 2011;52(Suppl 1):S75-S82.

6. Louie JK, Acosta M, Winter K, et al and the California Pandemic (H1N1) Working Group. Factors associated with death or hospitalization due to pandemic 2009 influenza A (H1N1) infection in California. JAMA. 2009;302(17):1896-1902.

7. Hayden F. Developing new antiviral agents for influenza treatment: what does the future hold? Clin Infect Dis. 2009;48(Suppl 1):S3-S13.

8. Yu Y, Garg S, Patricia A, et al. Peramivir use for treatment of hospitalized patients with influenza A (H1N1) pdm09 under emergency use authorization, October 2009-June 2010. Clin Infect Dis. 2012;55(1):8-15.

9. Sorbello A, Jones SC, Carter W, et al. Emergency use authorization for intravenous peramivir: evaluation of safety in the treatment of hospitalized patients infected with $2009 \mathrm{H} 1 \mathrm{~N} 1$ influenza A virus. Clin Infect Dis. 2012;55(1):1-7.

10. Hata A, Akashi-Ueda R, Takamatsu K, Matsumura T. Safety and efficacy of peramivir for influenza treatment. Drug Des Devel Ther. 2014;8: 2017-2038.

11. Ison MG. Optimizing antiviral therapy for influenza: understanding the evidence. Expert Rev Anti Infect Ther. 2015;13(4):417-425.

12. McLaughlin MM, Skoglund EW, Ison MG. Peramivir: an intravenous neuraminidase inhibitor. Expert Opin Pharmacother. 2015;16(12): 1889-1900.

13. US Food and Drug Administration. FDA approves Rapivab to treat flu infection. Silver Spring, MD: US Food and Drug Administration. Available from: http://www.fda.gov/NewsEvents/Newsroom/PressAnnouncements/ucm427755.htm. Accessed June 23, 2015.

14. Moscona A. Neuraminidase inhibitors for influenza. $N$ Engl J Med. 2005;353(13):1363-1373.

15. Li W, Escarpe PA, Eisenberg EJ, et al. Identification of GS 4104 as an orally bioavailable prodrug of the influenza virus neuraminidase inhibitor GS 4071. Antimicrob Agents Chemother. 1998;42(3):647-653.

16. Hayden FG, Treanor JJ, Betts RF, et al. Safety and efficacy of the neuraminidase inhibitor GG167 in experimental human influenza. JAMA. 1996;275(4):295-299.

17. Nguyen HT, Sheu TG, Mishin VP, Klimov AI, Gubareva LV. Assessment of pandemic and seasonal influenza A (H1N1) virus susceptibility to neuraminidase inhibitors in three enzyme activity inhibition assays. Antimicrob Agents Chemother. 2010;54(9):3671-3677.

18. Mendel DB, Tai CY, Escarpe PA, et al. Oral administration of a prodrug of the influenza virus neuraminidase inhibitor GS 4071 protects mice and ferrets against influenza infection. Antimicrob Agents Chemother. 1998;42(3):640-646.

19. Babu YS, Chand P, Bantia S, et al. BCX-1812 (RWJ-270201): discovery of a novel, highly potent, orally active, and selective influenza neuraminidase inhibitor through structure-based drug design. JMed Chem. 2000;43(19):3482-3486.

20. Bantia S, Arnold CS, Parker CD, et al. Anti-influenza virus activity of peramivir in mice with single intramuscular injection. Antiviral Res. 2006;69(1):39-45.

21. Bantia S, Upshaw R, Babu YS. Characterization of the binding affinities of peramivir and oseltamivir carboxylate to the neuraminidase enzyme. Antiviral Res. 2011;91(3):288-291. 
22. Mineno T, Miller MJ. Stereoselective total synthesis of racemic BCX1812 (RWJ-270201) for the development of neuraminidase inhibitors as anti-influenza agents. J Org Chem. 2003;68(17):6591-6596.

23. Castillo R, Holland LE, Boltz DA. Peramivir and its use in H1N1 influenza. Drugs Today (Barc) 2010;46(6):399-408.

24. Beigel J, Harmon LA, Collis PJ, et al. Pharmacokinetics and safety evaluations of escalating doses of peramivir administered intravenously in healthy volunteers. Presented at: 47th Interscience Conference on Antimicrobial Agents and Chemotherapy (ICAAC); September 17-20, 2007; Chicago, IL. Abstract A-1408.

25. Barroso L, Treanor J, Gubareva L, et al. Efficacy and tolerability of the oral neuraminidase inhibitor in experimental human influenza: randomized, controlled trials for prophylaxis and treatment. Antivir Ther. 2005;10(8):901-910.

26. Atiee G, Collis P, McCullough A, Dobo S, Elder J, Sheridan B. Single dose injections of i.v. and i.m. peramivir are bioequivalent and well tolerated. Poster presented at: Interscience Conference on Antimicrobial Agents Chemotherapy; September 5-9; 2014; Washington, DC.

27. Matsuo Y, Ishibashi T, Hollister AS, Wajima T. Population pharmacokinetics of peramivir in healthy volunteers and influenza patients. Antimicrob Agents Chemother. 2015;59(11):6755-6762.

28. Zhang D, Du A, Zhang L, et al. Pharmacokinetics of peramivir after single intravenous doses in healthy Chinese subjects. Xenobiotica. 2014;45(3):239-243.

29. Sato M, Ito M, Suzuki S, et al. Influenza viral load and peramivir kinetics after single administration and proposal of regimens for peramivir administration against resistant variants. Antimicrob Agents Chemother. 2015;59(3):1643-1649.

30. Bentley ML, Hollistera AS, Hansenb AC, Smith JA, Cain JS. Peramivir pharmacokinetics in a patient receiving continuous veno-venous hemodiafiltration during the $2009 \mathrm{H} 1 \mathrm{~N} 1$ influenza A pandemic. Int $J$ Clin Pharm Ther. 2014;52(12):1105-1111.

31. Tang X, He H, Sun B, et al. ARDS associated with pneumonia caused by avian influenza A H7N9 virus treated with extracorporeal membrane oxygenation. Clin Respir J. 2015;9(3):380-384.

32. Govorkova EA, Leneva IA, Goloubeva OG, et al. Comparison of efficacies of RWJ-270201, zanamivir, and oseltamivir against H5N1, H9N2, and other avian influenza viruses. Antimicrob Agents Chemother 2001;45(10):2723-2732.

33. Farooqui A, Huang L, Wu S, et al. Assessment of antiviral properties of peramivir agains $\mathrm{H} 7 \mathrm{~N} 9$ avian influenza virus in an experimental mouse model. Antimicrob Agents Chemother. 2015;59(12):7255-7264.

34. Dapat C, Kondo H, Dapat IC, et al. Neuraminidase inhibitor susceptibility profile of pandemic and seasonal influenza viruses during the 2009-2010 and 2010-2011 influenza seasons in Japan. Antiviral Res. 2013;99(3):261-269.

35. Leang SK, Kwok S, Sullivan SG, et al. Peramivir and laninamivir susceptibility of circulating influenza A and B viruses. Influenza Other Respir Viruses. 2013;8(2):135-139.

36. Baz M, Abed Y, Boivin G. Characterization of drug-resistant recombinant influenza $\mathrm{A} / \mathrm{H} 1 \mathrm{~N} 1$ viruses selected in vitro with peramivir and zanamivir. Antiviral Res. 2007;74(2):159-162.

37. Takashita E, Meijer A, Lackenby A, et al. Global update on the susceptibility of human influenza viruses to neuraminidase inhibitors, 2013-2014. Antiviral Res. 2015;117:27-38.

38. Takashita E, Fujisaki S, Kishida N, et al. Characterization of neuraminidase inhibitor-resistant influenza A (H1N1) pdm09 viruses isolated in four seasons during pandemic and post-pandemic periods in Japan. Influenza Other Respir Viruses. 2013;7(6):1390-1399.

39. Memoli MJ, Hrabal RJ, Hassantoufighi A, Eichelberger MC, Taubenberger JK. Rapid selection of oseltamivirand peramivir-resistant pandemic $\mathrm{H} 1 \mathrm{~N} 1$ virus during therapy in 2 immunocompromised hosts. Clin Infect Dis. 2010;50(9):1252-1255.

40. Takashita E, Ejima M, Itoh R, et al. A community cluster of influenza A (H1N1) pdm09 virus exhibiting cross-resistance to oseltamivir and peramivir in Japan, November to December 2013. Euro Surveill. 2014;19(1):1-6.
41. Nguyen HT, Trujillo AA, Sheu TG, et al. Analysis of influenza viruses from patients clinically suspected of infection with an oseltamivir resistant virus during the 2009 pandemic in the United States. Antiviral Res. 2012;93(3):381-386.

42. Hurt AC, Hardie K, Wilson NJ, et al. Community transmission of oseltamivir-resistant A (H1N1) pdm09 influenza. N Engl J Med. 2011;365(26): 2541-2542.

43. Sleeman K, Mishin VP, Guo Z, et al. Antiviral susceptibility of variant influenza A (H3N2) viruses isolated in the United States from 2011 to 2013. Antimicrob Agents Chemother. 2014;58(4):2045-2051.

44. Farrukee R, Mosse J, Hurt AC. Review of the clinical effectiveness of the neuraminidase inhibitors against influenza B viruses. Expert Rev Anti Infect Ther. 2013;11(11):1135-1145.

45. BioCryst Pharmaceuticals. Evaluation of the efficacy and safety of peramivir in subjects with uncomplicated acute influenza. Available from: https:/clinicaltrials.gov/ct2/show/NCT00419263. NLM identifier: NCT00419263. Accessed November 30, 2015.

46. Atiee G, Laughlin A, Tellier G, et al. Virologic analysis of influenza viruses after therapy with a single intramuscular dose of the neuraminidase inhibitor peramivir versus placebo in patients with influenza in the outpatient setting. Presented at: 49th Annual Meeting of the Infectious Diseases Society of America; October 20-23; 2011; Boston, MA.

47. Kohno S, Kida H, Mizuguchi M, Shimada J. Efficacy and safety of intravenous peramivir for treatment of seasonal influenza virus infection. Antimicrob Agents Chemother. 2010;54(11):4568-4574.

48. Kohno S, Kida H, Mizuguchi M, et al. Intravenous peramivir for treatment of influenza A and B virus infection in high-risk patients. Antimicrob Agents Chemother. 2011;55(6):2803-2812.

49. Kohno S, Yen MY, Cheong HJ, et al. Comparison of single-dose intravenous peramivir with oral oseltamivir in patients with seasonal influenza virus infection: a phase III randomized, double-blind study. Antimicrob Agents Chemother. 2011;55(11):5267-5276.

50. Ison MG, Hui DS, Clezy K, et al. A clinical trial of intravenous peramivir compared with oral oseltamivir for the treatment of seasonal influenza in hospitalized adults. Antivir Ther. 2013;18(5):651-661.

51. Hernandez JE, Adiga R, Armstrong R, et al. Clinical experience in adults and children treated with intravenous peramivir for 2009 influenza A (H1N1) under an emergency IND program in the United States. Clin Infect Dis. 2011;52(6):696-706.

52. de Jong MD, Ison MG, Monto AS, et al. Evaluation of intravenous peramivir for treatment of influenza in hospitalized patients. Clin Infect Dis. 2014;59(12):e172-e185.

53. Yoshino Y, Seo K, Koga I, Kitazawa T, Ota Y. Clinical efficacy of peramivir in adult patients with seasonal influenza during the winter of 2012 in Japan. Clin Respir J. 2014;9(2):228-232.

54. Ison MG, Fraiz J, Heller B, et al. Intravenous peramivir for treatment of influenza in hospitalized patients. Antivir Ther. 2014;19(4):349-361.

55. Sugaya N, Kohno S, Ishibashi T, Wajima T, Takahashi T. Efficacy, safety, and pharmacokinetics of intravenous peramivir in children with 2009 pandemic A (H1N1) influenza virus infection. Antimicrob Agents Chemother. 2012;56(1):369-377.

56. Shobugawa Y, Saito R, Sato I, et al. Clinical effectiveness of neuraminidase inhibitors -oseltamivir, zanamivir, laninamivir, and peramivir - for treatment of influenza A (H3N2) and A (H1N1) pdm09 infection: an observational study in the 2010-2011 influenza season in Japan. J Infect Chemother. 2012;18(6):858-864.

57. Hikita T, Hikita H, Hikita F, Hikita N, Hikita S. Clinical effectiveness of peramivir in comparison with other neuraminidase inhibitors in pediatric influenza patients. Int J Pediatr. 2012;2012:1-4.

58. Sugaya N, Shinjoh M, Mitamura K, Takahashi T. Very low pandemic influenza A (H1N1) 2009 mortality associated with early neuraminidase inhibitor treatment in Japan: analysis of 1,000 hospitalized children. $J$ Infect. 2011;63(4):288-294.

59. Louie JK, Yang S, Samuel MC, Uyeki TM, Schechter R. Neuraminidase inhibitors for critically ill children with influenza. Pediatrics. 2013;132(6):e1539-e1545. 
60. Louie JK, Yang S, Yen C, Acosta M, Schechter R, Uyeki TM. Use of intravenous peramivir for treatment of severe influenza A (H1N1) pdm09. PLoS One. 2012;7(6):e40261.

61. Dunning J, Baillie JK, Cao B, et al. Antiviral combinations for severe influenza. Lancet Infect Dis. 2014;14(12):1259-1270.

62. Atiee G, Lasseter K, Baughman S, et al. Absence of pharmacokinetic interaction between intravenous peramivir and oral oseltamivir or rimantadine in humans. J Clin Pharmacol. 2012;52(9):1410-1419.

63. Peramivir ${ }^{\circledR}$ (Rapivab) [package insert]. Durham, NC: BioCryst Pharmaceuticals, Inc.; 2014.

64. Dobo SM, Elder J, Collis P. Safety of peramivir in hospitalized influenza. Poster \#1169 presented at: 53rd Annual Meeting of the Infectious Diseases Society of America; October 8-11; Philadelphia, PA.

65. Komeda T, Ishii S, ItohY, et al. Post-marketing safety and effectiveness evaluation of the intravenous anti-influenza neuraminidase inhibitor peramivir (I): a drug use investigation. J Infect Chemother. 2014;20(11):689-695.
66. Komeda T, Ishii S, Itoh Y, et al. Post-marketing safety and effectiveness evaluation of the intravenous anti-influenza neuraminidase inhibitor peramivir (II): a pediatric drug use investigation. J Infect Chemother. 2014; 21(3):194-201.

67. Hayashi K, Iwasa K, Morinaga A, Ono K, Yamada M. Exacerbation of myasthenia gravis by intravenous peramivir. Muscle Nerve. 2015:51(6): 935-936.

68. Harada-Shirado K, Ikeda K, Furukawa M, et al. Severe immune thrombocytopenia possibly elicited by the anti-influenza viral agent peramivir. Intern Med. 2014;53(20):2369-2371.

69. Ariano RE, Sitar DS, Zelenitsky SA, et al. Enteric absorption and pharmacokinetics of oseltamivir in critically ill patients with pandemic (H1N1) influenza. CMAJ. 2010;182(4):357-363.

70. Taylor WR, Thinh BN, Anh GT, et al. Oseltamivir is adequately absorbed following nasogastric administration to adult patients with severe $\mathrm{H} 5 \mathrm{~N} 1$ influenza. PLoS One. 2008;3(10):e3410.1-6.
Infection and Drug Resistance

\section{Publish your work in this journal}

Infection and Drug Resistance is an international, peer-reviewed openaccess journal that focuses on the optimal treatment of infection (bacterial, fungal and viral) and the development and institution of preventive strategies to minimize the development and spread of resistance. The journal is specifically concerned with the epidemiology of antibiotic

\section{Dovepress}

resistance and the mechanisms of resistance development and diffusion in both hospitals and the community. The manuscript management system is completely online and includes a very quick and fair peerreview system, which is all easy to use. Visit http://www.dovepress.com/ testimonials.php to read real quotes from published authors.

Submit your manuscript here: https://www.dovepress.com/infection-and-drug-resistance-journal 